\title{
Nutrients losses via runoff from soils amended with cow manure composted with leaf litter
}

\author{
Zobia Anwar ${ }^{1}$, An Ping 2 , Bushra Haroon ${ }^{1}$, Muhammad Irshad ${ }^{1,2 *}$, Gary Owens ${ }^{3}$ \\ ${ }^{1}$ Department of Environmental Sciences, COMSATS University Islamabad Abbottabad Campus Ab- \\ bottabad city Pakistan. ${ }^{2}$ Arid Land Research Center, Tottori University, Tottori city Japan 680-0001 \\ ${ }^{3}$ Environmental Contaminants Group, Future Industries Institute, University of South Australia, Maw- \\ son Lakes Campus, Mawson Lakes, SA 5095, Australia.*Corresponding author: mirshad@ciit.net.pk
}

\begin{abstract}
Application of composted manures has previously been proposed as soil amendments capable of retarding nutrients losses via surface runoff, thereby stimulating infiltration rates. A study was carried out under natural rainfall conditions to assess the effects of cow manure after composting with maple and poplar leaf litter on nutrient runoff from two types of soils, a sandy loam and silt loam. Composted manure without added leaf litter to the soil was considered as a control treatment. Cow manure co-composted with leaf litter at four ratios (1:0, 1:1, 1:2 and 1:3). Soils were packed in the plastic lined wooden trays and the soil surface was mixed with the co-composted manure at rates of 10 and $20 \mathrm{t} \mathrm{ha}^{-1}$. Runoff samples were collected from the sloped trays (5\%) during three rainfall events. Inorganic $\mathrm{N}\left(\mathrm{NO}_{3}\right.$ plus $\left.\mathrm{NH}_{4}\right), \mathrm{P}$ and $\mathrm{K}$ concentrations were measured in the runoff. Application of manure amendments derived from composting with leaf litter to the soil reduced the nutrients losses in the order of 1:3 $<1: 2<1: 1<1: 0$ regardless of the kind of leaf litter used. Irrespective of soil and application rates, $\mathrm{N}$ losses in the runoff were lowered with manure co-composted with leaf litter. Nutrients losses in the runoff were enhanced with higher manure application rates, depending on the type of the soil treated. It was concluded that application of manure amendments derived from composting with plant leaf litter was a useful option in reducing nutrients losses from soils.
\end{abstract}

Keywords: Composted manure, leaf litter, plant nutrients, runoff losses, natural rainfall 


\section{Introduction}

Application of composted manures to agricultural lands often provides a rich source of relatively cheap plant nutrients, including $\mathrm{N}, \mathrm{P}$ and $\mathrm{K}$, which produce crop yields equivalent to those obtained using more costly inorganic fertilizers (Gilley et al., 2007). Intensive livestock production and poor agricultural management have resulted to excessive loading of soil with phosphors, thereby contributing to environmental pollution and impairment of water quality (Asma et al., 2017). Mahmood et al. (2017) reported a sustainable nutrient management system to enhance crop productivity with high efficiency and minimum nutrient losses. The disposal of animal wastes is a considerable issue in the animal husbandry sector and thus the simple aerobic degradation of such biological wastes via composting beneficially reuses the animal waste as a value added fertilizer or soil amendment (Neves et al., 2009). During composting microbes devour biodegradable organic matter and, compared with the original waste, produce a high quality compost enriched with $\mathrm{N}$ and $\mathrm{P}$, that are less prone to leaching to groundwater and/or surface runoff (Easton and Petrovic, 2004). Higher application rates of fresh manure are unsustainable and ultimately led to the deterioration of soil, making manure application in cropping systems more undesirable than mineral fertilizers (Laguë et al., 2005). On the other hand, compost derived from fresh manure is effective at controlling soil erosion, increases soil organic matter and beneficially alters the soil's physicochemical properties, magnify the nutritional base for soil microorganisms which curtails both soil compaction and erosion (Gilley et al., 2002; Cerdà and Doerr, 2008). Many types of organic amend- ments have been studied for their possible manipulation in intercepting soil losses (Tejada and Gonzalez, 2008). Application of organic material to agricultural soils is beneficial because it enhances the soil's organic $\mathrm{C}$, resulting in productive and advantageous effects on the soil characteristics (Tejada et al., 2006).

As with $\mathrm{P}, \mathrm{NO}_{3}-\mathrm{N}$ runoff can be detrimental and develops a hypoxic zone $\left(<2 \mathrm{mg} \mathrm{L}^{-1}\right)$ for marine life when transported from land to rivers and lakes. Additionally, water bodies having $\mathrm{NH}_{4}-\mathrm{N}$ levels $>2.5 \mathrm{mg} \mathrm{L}^{-1}$ may detrimentally affect aquatic organisms (Turner et al., 1997). Denitrification, leaching, mineralization, nitrification, and volatilization are the main microbiological and physical processes involved in $\mathrm{N}$ transformation following land application (Reynolds, 2006). While dairy manure is considered to be a rich source of $\mathrm{N}$, the amount of available $\mathrm{N}$ in dairy manure is quite low, which has been attributed to $\mathrm{N}$ losses through $\mathrm{NH}_{3}-$ $\mathrm{N}$ volatilization. These losses can be minimized by the effective utilization of organic wastes which contribute directly to the adsorption of $\mathrm{NH}_{4}-\mathrm{N}$ and formation of organic acids through microbial activity, ultimately reducing manure $\mathrm{pH}$ (Subair et al., 1999). Shah et al. (2016) reported better maize nitrogen recovery and dry matter production after application of treated solid cattle manure.

In Pakistan, waste resources are plentiful, with materials such as the tree litter of maple (Platanus orientalis L.) and poplar residues (Populus tremula L.) being a potential rich source of $\mathrm{C}$ but are currently underutilized, being either carbonized or simply dumped to land. Plant derived lignin cellulosic materials are also useful as soil amendments 
because they decrease losses of nutrients through runoff when co-composted with $\mathrm{N}$-rich organic waste (Hubbe et al., 2010).

Currently, rainfall stimulators have been widely utilized in the laboratory to examine nutrient losses and soil erosion. While much research have also been carried out to demonstrate the effects of composted manure derived from different agro-wastes on the growth, development, production and properties of soil-plant systems (e.g. Rodriguez et al., 2006; Zhang and He, 2006; Wright et al., 2007; Hubbe et al., 2010; Irshad et al., 2014; Hazbavi and Sadeghi, 2016). Knowledge of the optimal application ratios of co-composted cow manure to local tree litter for controlling nutrient loss via runoff under natural rainfall events remains scant. Therefore, a study was undertaken to examine the potential effect of organic amendments i.e., co-composted cow manure with either maple or polar leaf residues on nutrients losses in surface runoff from sandy loam and silt loam soils.

\section{Materials and Methods}

\subsection{Organic waste collection}

Fresh cow dung was collected from local farms and leaf litter of maple (Platanus orientalis L.) and poplar (Populus tremula L.) were collected from different locations across Abbottabad city $\left(34.1558^{\circ} \mathrm{N}, 73.2194^{\circ}\right.$ E), Pakistan. Maple and poplar leaf litters were air dried and then manually chopped to about $2-3 \mathrm{~cm}$ before composting.

\subsection{Composting}

Composting was initiated by mixing fresh cow manure $(\mathrm{CM})$ with either chopped maple leaf res- idues (MR) or poplar leaf residues (PR), at four different ratios of leaf residue (MR or PR) to $\mathrm{CM}$ (1:0, 1:1, 1:2 and 1:3; In figures these ratios are denoted as T1, T2, T3 and T4, respectively) in 15L plastic buckets and composted for 120 days at room temperature and $30 \%(\mathrm{w} / \mathrm{w})$ moisture content. All treatments were triplicated. During the composting period manure mixtures were mechanically aerated and mixed periodically, while after termination of the composting process, manure samples were air dried and screened to pass a $2 \mathrm{~mm}$ sieve prior to the analysis of selected parameters (Table 2-3). Total carbon was determined using the dry combustion method (Nelson and Sommers, 1982). The milled compost samples were digested in a mixture of nitric $\left(\mathrm{HNO}_{3}\right)$ and perchloric $\left(\mathrm{HClO}_{4}\right)$ acids (3:1) to determine total element concentrations (i.e., phosphorus $(\mathrm{P})$, potassium $(\mathrm{K})$, calcium $(\mathrm{Ca})$, magnesium $(\mathrm{Mg})$, sodium $(\mathrm{Na})$, copper $(\mathrm{Cu})$, iron $(\mathrm{Fe})$, manganese $(\mathrm{Mn})$, zinc $(\mathrm{Zn})$, nickel (Ni) and cadmium (Cd). These elements except $\mathrm{P}$ were analyzed using atomic absorption spectrophotometer (AAS) (Model AAnalyst 700, Perkin Elmer) (Miller, 1998). Phosphorus content was determined calorimetrically at $710 \mathrm{~nm}$ using a spectrophotometer (Olsen and Sommers 1982). Total N was determined by the Kjeldahl method. Colorimetric nitrate $\left(\mathrm{NO}_{3}-\mathrm{N}\right)$ was determined following Anderson and Ingram (1993) and ammonium $\left(\mathrm{NH}_{4}-\mathrm{N}\right)$ was determined following the Indophenol blue method (Keeney and Nelson, 1982) after extraction with $2 \mathrm{M} \mathrm{KCl}$. The $\mathrm{pH}$ and electrical conductivity (EC) of co-composted manures and soils were measured in water: manure and water: soil suspensions of 1:5 ratio with $\mathrm{pH}$ (Janway 3505) and EC (Janway 470) meters, respectively. 
Table 2. Chemical composition of manure co-composted with maple leaf litter at different ratios.

\begin{tabular}{|c|c|c|c|c|c|}
\hline Parameters & Unit & $1: 0$ & $1: 1$ & $1: 2$ & $1: 3$ \\
\hline Total C & $\mathrm{g} \mathrm{kg}^{-1}$ & 366.8 & 375.4 & 378.8 & 395.8 \\
\hline Total N & $\mathrm{g} \mathrm{kg}^{-1}$ & 17.2 & 14.4 & 13.8 & 11.6 \\
\hline $\mathrm{NO}_{3}$ & $\mathrm{mg} \mathrm{kg}^{-1}$ & 91.6 & 86.8 & 74.5 & 67.9 \\
\hline $\mathrm{NH}_{4}$ & $\mathrm{mg} \mathrm{kg}^{-1}$ & 59.6 & 56.8 & 54.5 & 37.9 \\
\hline Total P & $\mathrm{mg} \mathrm{kg}^{-1}$ & 167.7 & 175.7 & 187.8 & 207.8 \\
\hline Total Ca & $\mathrm{mg} \mathrm{kg}^{-1}$ & 167.2 & 188.4 & 198.6 & 212.3 \\
\hline Total Mg & $\mathrm{mg} \mathrm{kg}^{-1}$ & 132.6 & 148.6 & 161.6 & 179.2 \\
\hline Total K & $\mathrm{mg} \mathrm{kg}^{-1}$ & 400.4 & 467.8 & 475.8 & 491.3 \\
\hline Total Na & $\mathrm{mg} \mathrm{kg}^{-1}$ & 45.6 & 45.0 & 35.6 & 30.7 \\
\hline Total Cu & $\mathrm{mg} \mathrm{kg}^{-1}$ & 93.1 & 84.5 & 76.7 & 66.8 \\
\hline Total Fe & $\mathrm{mg} \mathrm{kg}^{-1}$ & 184.9 & 178.8 & 171.6 & 162.6 \\
\hline Total Mn & $\mathrm{mg} \mathrm{kg}^{-1}$ & 124.8 & 115.5 & 108.5 & 102.3 \\
\hline Total Zn & $\mathrm{mg} \mathrm{kg}^{-1}$ & 140.6 & 122.7 & 106.9 & 86.7 \\
\hline Total Ni & $\mathrm{mg} \mathrm{kg}^{-1}$ & 2.7 & 2.4 & 2.5 & 2.1 \\
\hline Total Cd & $\mathrm{mg} \mathrm{kg}^{-1}$ & 1.5 & 1.1 & 1.2 & 0.8 \\
\hline EC (1:5) & $\mathrm{dS} \mathrm{m}^{-1}$ & 5.0 & 5.3 & 5.6 & 5.9 \\
\hline pH (1: 5) & & 8.7 & 8.2 & 8.0 & 7.8 \\
\hline
\end{tabular}

Table 3. Chemical composition of manure co-composted with poplar leaf litter at different ratios.

\begin{tabular}{llllll}
\hline Parameters & Unit & $1: 0$ & $1: 1$ & $1: 2$ & $1: 3$ \\
\hline Total C & $\mathrm{g} \mathrm{kg}^{-1}$ & 366.8 & 374.4 & 378.3 & 397.5 \\
Total N & $\mathrm{g} \mathrm{kg}^{-1}$ & 18.0 & 16.7 & 15.6 & 15.0 \\
NO3 & $\mathrm{mg} \mathrm{kg}^{-1}$ & 91.6 & 86.8 & 74.5 & 67.9 \\
$\mathbf{N H}$ & $\mathrm{mg} \mathrm{kg}_{\mathbf{4}}$ & 59.6 & 60.3 & 57.6 & 34.8 \\
Total P & $\mathrm{mg} \mathrm{kg}^{-1}$ & 167.7 & 180.9 & 196.4 & 206.3 \\
Total Ca & $\mathrm{mg} \mathrm{kg}^{-1}$ & 167.2 & 178.6 & 188.2 & 203.6 \\
Total Mg & $\mathrm{mg} \mathrm{kg}^{-1}$ & 132.6 & 143.9 & 165.2 & 172.6 \\
Total K & $\mathrm{mg} \mathrm{kg}^{-1}$ & 400.4 & 467.9 & 489.0 & 511.8 \\
Total Na & $\mathrm{mg} \mathrm{kg}^{-1}$ & 41.0 & 33.4 & 31.2 & 25.6 \\
Total Cu & $\mathrm{mg} \mathrm{kg}^{-1}$ & 93.1 & 63.5 & 66.2 & 56.1 \\
Total Fe & $\mathrm{mg} \mathrm{kg}^{-1}$ & 184.9 & 166.4 & 167.1 & 154.4 \\
Total Mn & $\mathrm{mg} \mathrm{kg}^{-1}$ & 124.8 & 105.2 & 98.5 & 82.7 \\
Total Zn & $\mathrm{mg} \mathrm{kg}^{-1}$ & 140.6 & 115.2 & 100.2 & 87.5 \\
Total Ni & $\mathrm{mg} \mathrm{kg}^{-1}$ & 2.7 & 2.3 & 1.8 & 1.9 \\
Total Cd & $\mathrm{mg} \mathrm{kg}^{-1}$ & 1.5 & 1.1 & 1.0 & 0.9 \\
EC (1:5) & $\mathrm{dS} \mathrm{m}^{-1}$ & 5.0 & 6.1 & 6.3 & 6.8 \\
pH (1: 5) & & 8.7 & 8.3 & 8.1 & 7.7 \\
\hline
\end{tabular}




\subsection{Runoff experiment}

Top soils $(0-20 \mathrm{~cm})$ were sampled from different sites of Abbottabad, being a part of the lesser Himalayan mountain range situated in the province of Khyber Pakhtunkhwa, Pakistan. Soil texture was determined using a pipette method (Gee and Bauder, 1986) and classified as sandy loam and silt loam based on textural analysis. Soils were air-dried for 2 days and thereafter screened through a $2 \mathrm{~mm}$ sieve prior to determination of the physico-chemical properties given in Table 1. During this experiment wooden trays (size: $0.5 \mathrm{~m} \times 0.5 \mathrm{~m} \times 0.1 \mathrm{~m}$ ), layered at the bottom and sides with plastic sheets, were packed with $10 \mathrm{~kg}$ of each soil. Soils were amended with co-composted manure leaf litter mixtures (as given above). The manure compost was added at a rate of $10 \mathrm{tha}^{-1}$ and $20 \mathrm{t} \mathrm{ha}^{-1}$ (based on 2 million $\mathrm{kg}$ soil per plow layer per ha).
The application of composted manure to soil without leaf litter (1:0) was used as a control treatment. The experiment consisted of $(4 \times 2 \times 2 \times 2)$ factorial (ratios of cow manure co-composted with plant residues $\mathrm{x}$ tree residues $\mathrm{x}$ soil types $\mathrm{x}$ application rates) resulting in 32 experimental units in a completely randomized block design (RBD), with three replications. The trays were placed at about 5\% slope in open fields. Soils packed in the trays were moistened and incubated at field capacity for 2 days. The outlet of each tray was connected to a plastic bottle which enabled runoff water to be collected during natural rainfall events. This practice was repeated for three rain events. The runoff water was filtered using a filter paper (Whatman 42). Water soluble $\mathrm{NO}_{3}-\mathrm{N}, \mathrm{NH}_{4}-\mathrm{N}, \mathrm{P}$ and $\mathrm{K}$ were determined following the procedures as stated above. The results of each determination were averaged over all three rainfall events.

Table 1. Chemical composition of soils used for the study.

\begin{tabular}{llll}
\hline Parameters & Unit & Sandy loam soil & Silt loam soil \\
& & & \\
\hline & & & \\
Total C & $\mathrm{g} \mathrm{kg}^{-1}$ & 25.6 & $\mathbf{2 8 . 3}$ \\
Total N & $\mathrm{mg} \mathrm{kg}^{-1}$ & 35.8 & $\mathbf{5 6 . 6}$ \\
NO3 & $\mathrm{mg} \mathrm{kg}^{-1}$ & 6.6 & $\mathbf{1 5 . 3}$ \\
NH4 & $\mathrm{mg} \mathrm{kg}$ & 8.2 & $\mathbf{1 0 . 8}$ \\
Total P & $\mathrm{mg} \mathrm{kg}^{-1}$ & 45.7 & $\mathbf{6 7 . 8}$ \\
Total Ca & $\mathrm{mg} \mathrm{kg}^{-1}$ & 218.7 & $\mathbf{2 6 7 . 8}$ \\
Total Mg & $\mathrm{mg} \mathrm{kg}$ & 128.6 & $\mathbf{1 3 1 . 6}$ \\
Total K & $\mathrm{mg} \mathrm{kg}^{-1}$ & 147.8 & $\mathbf{1 5 8 . 8}$ \\
Total Na & $\mathrm{mg} \mathrm{kg}^{-1}$ & 23.4 & $\mathbf{3 4 . 6}$ \\
Total Cu & $\mathrm{mg} \mathrm{kg}^{-1}$ & 34.5 & $\mathbf{5 6 . 4}$ \\
Total Fe & $\mathrm{mg} \mathrm{kg}^{-1}$ & 67.8 & $\mathbf{7 8 . 6}$ \\
Total Mn & $\mathrm{mg} \mathrm{kg}^{-1}$ & 47.5 & $\mathbf{6 7 . 5}$ \\
Total Zn & $\mathrm{mg} \mathrm{kg}^{-1}$ & 56.7 & $\mathbf{7 6 . 9}$ \\
Total Ni & $\mathrm{mg} \mathrm{kg}^{-1}$ & 2.5 & $\mathbf{3 . 0}$ \\
Total Cd & $\mathrm{mg} \mathrm{kg}^{-1}$ & 0.3 & $\mathbf{1 . 9}$ \\
EC (1:5) & $\mathrm{dS} \mathrm{m}^{-1}$ & 0.5 & $\mathbf{0 . 3}$ \\
pH (1: 5) & & $\mathbf{7 . 6}$ & $\mathbf{7 . 8}$ \\
\hline
\end{tabular}




\subsection{Statistical analysis}

Analysis of variance (ANOVA) was performed using Statview software and differences between means were assessed using the least significance difference (LSD) test at $P<0.05$.

\section{Results}

\subsection{Nitrogen concentration}

Soils amended with co-composts of different ratios of cow manure: tree residue $(1: 1,1: 2$ and $1: 3)$ all lowered the runoff concentrations of inorganic $\mathrm{N}$ compared to the control compost (1:0), where the amount of $\mathrm{N}$ in the runoff water was inversely related to the amount of leaf additives in the manure amendments. Runoff water from the sandy loam soil contained significant amounts of $\mathrm{N}, 10.8,8.6,7.9$ and $6.4 \mathrm{mg} \mathrm{L}^{-1}$ at a manure application rate of $10 \mathrm{t}$ ha $^{-1}$ followed by $17.7,16.3,15.4$ and $13.4 \mathrm{mg} \mathrm{L}^{-1}$ at a manure application rate of $20 \mathrm{t} \mathrm{ha}^{-1}$ for manure and maple leaf litters mixed at ratios of 1:0, $1: 1,1: 2$ and 1:3, respectively. Lower $\mathrm{N}$ concentrations in the runoff water (i.e., 6.1 and $13.6 \mathrm{mg} \mathrm{L}^{-1}$ ) were observed for the sandy loam soil after manure amendment together with poplar leaf litter (1:3) at the application rate of 10 and $20 \mathrm{t} \mathrm{ha}^{-1}$, respectively. The $\mathrm{N}$ concentrations in the runoff water collected from the sandy loam and silt loam soils were 10.6 and $12.9 \mathrm{mg} \mathrm{L}^{-1}$ at $10 \mathrm{t} \mathrm{ha}^{-1}$ after treatment with manure co-composted without leaf litter (1:0). Regardless of soil and application rates, $\mathrm{N}$ losses in the runoff were lowered with manure cocomposted with leaf litter in the order of $1: 3<1: 2$ $<1: 1<1: 0$.
The concentrations of both $\mathrm{NO}_{3}-\mathrm{N}$ and $\mathrm{NH}_{4}-\mathrm{N}$ in runoff after three sequential rainfall events for all treatments in sandy loam and silt loam soils under both application rates are presented in Figure 1-2. In general, the concentrations of $\mathrm{NO}_{3}$ and $\mathrm{NH}_{4}$ in runoff decreased with time and the amount of co-composts added to the soils. The large increase in losses of $\mathrm{NO}_{3}$, and $\mathrm{NH}_{4}$ to runoff during the first rainfall were stabilized or decreased during the second and third consecutive rainfall events. Mean $\mathrm{NO}_{3}$ and $\mathrm{NH}_{4}$ concentrations in the runoff water were significantly varied with the ratios of co-composted leaf litter fraction applied, decreasing in the order 1:0 $>1: 1>1: 2>1: 3$. The concentrations of both $\mathrm{NO}_{3}$ and $\mathrm{NH}_{4}$ in runoff from soils increased as the application rates of co-compost amendment. For instance, increased concentrations of $\mathrm{NO}_{3}$ and $\mathrm{NH}_{4}$ from 2.6 to $4.0 \mathrm{mg} \mathrm{L}^{-1}$, and from 2.8 to $3.5 \mathrm{mg} \mathrm{L}^{-1}$ were observed in the sandy loam soil at 10 and $20 \mathrm{tha}^{-1}$ respectively. Correspondingly, as the amount of poplar leaf litter in the compost increased in the order 1:1, 1:2 and 1:3 (manure:poplar) the amount of $\mathrm{NO}_{3}$ released from the silt loam soil decreased in the order $2.5>1.9>1.4 \mathrm{mg} \mathrm{L}^{-1}$ and $1.9>$ $1.3>0.8 \mathrm{mg} \mathrm{L}^{-1}$ at $20 \mathrm{tha}^{-1}$ and $10 \mathrm{t} \mathrm{ha}^{-1}$, respectivley. Likewise concentration of $\mathrm{NH}_{4}$ in the runoff from the sandy loam soil amended with a co-composted manure with maple leaf litter decreased with increasing fractions of maple leaf litter in the order $2.8>2.2>$ $1.7 \mathrm{mg} \mathrm{L}^{-1}$ and $2.1>1.6>1.1 \mathrm{mg} \mathrm{L}^{-1}$ for ratios of $1: 1$, $1: 2$ and 1:3 (manure: maple) at amendment rates of $20 \mathrm{t} \mathrm{ha}^{-1}$ and $10 \mathrm{t} \mathrm{ha}^{-1}$, respectively. Comparatively, $\mathrm{NH}_{4}$ released from the silt loam soil after application of co-composted amendment at 10 to $20 \mathrm{tha}^{-1}$ ranged from 5.4 to $9.2 \mathrm{mg} \mathrm{L}^{-1}$ and 4.0 to $6.2 \mathrm{mg} \mathrm{L}^{-1}$ in $1: 0$ and 1:3 mixture of cow manure: poplar leaf litter, respectively. 
Sandy loam
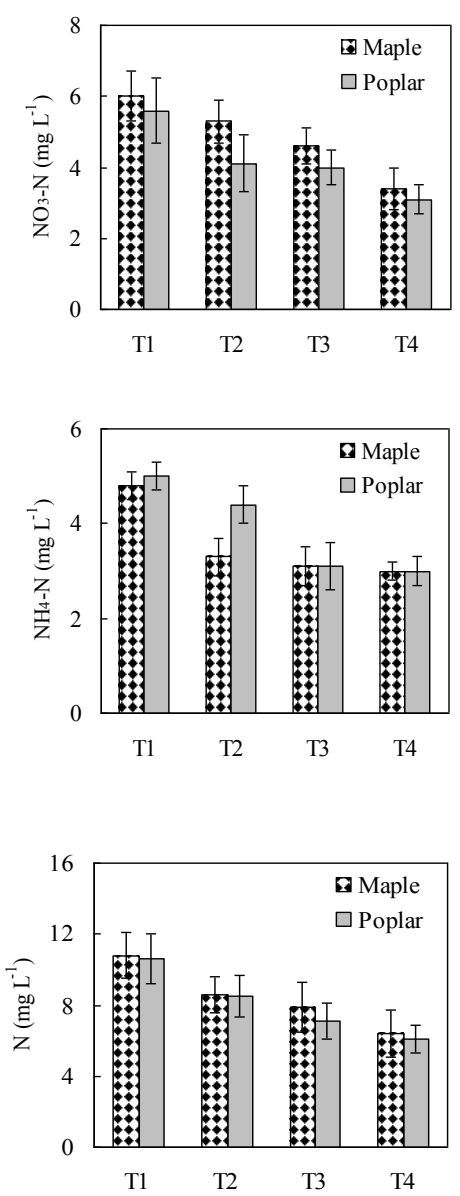

Silt loam
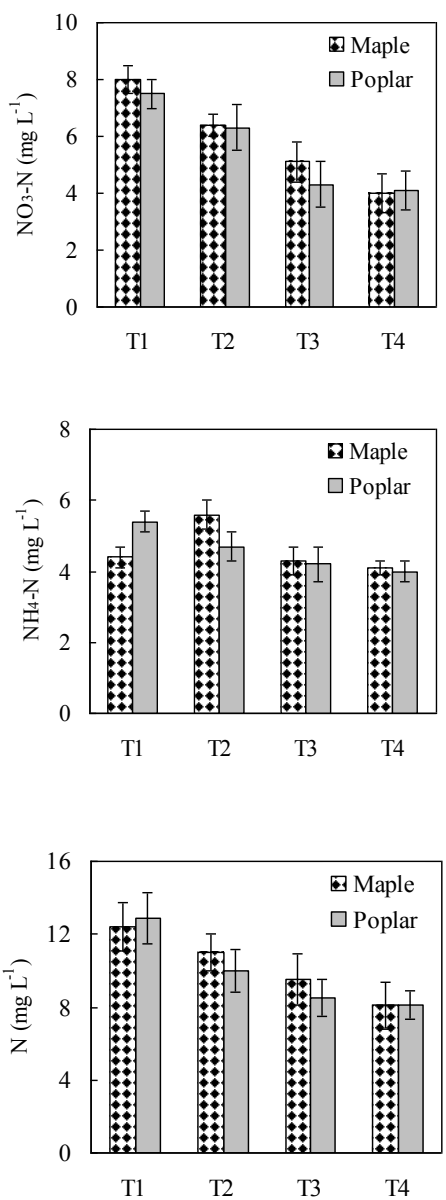

Manure-leaf litter treatments

Figure 1. $\mathrm{NO}_{3}, \mathrm{NH}_{4}$ and $\mathrm{N}$ in runoff water from soils treated with co-composted manure-maple / poplar leaf litter amendments at a rate of $10 \mathrm{tha}^{-1}$.For this and subsequent figures, T1, T2, T3 and T4 indicate 1:0, 1:1. 1:2 and 1:3 ratios of cow manure and leaf litter treatments. 
Sandy loam
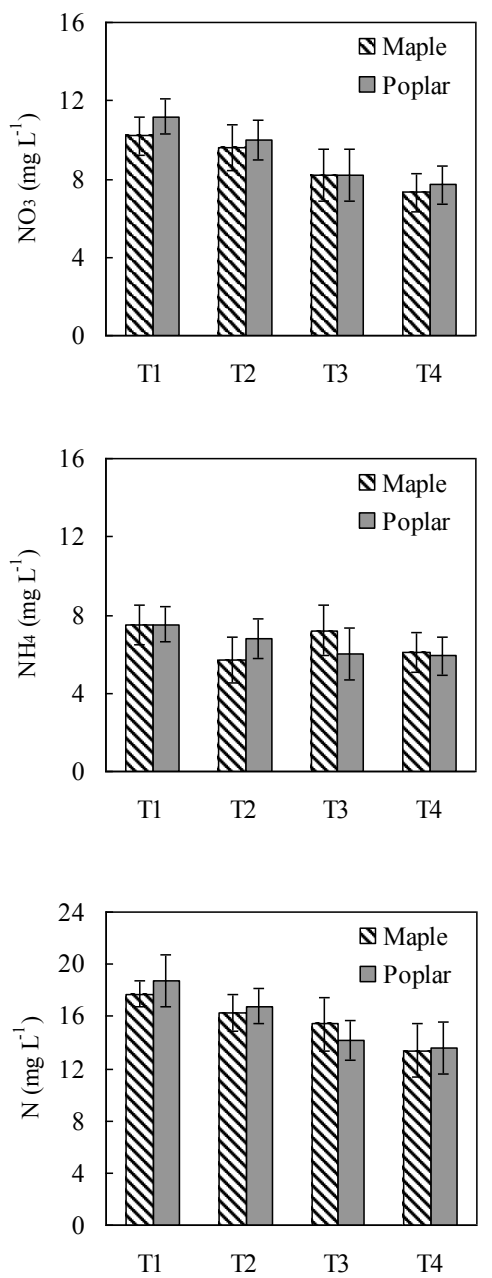

Silt loam
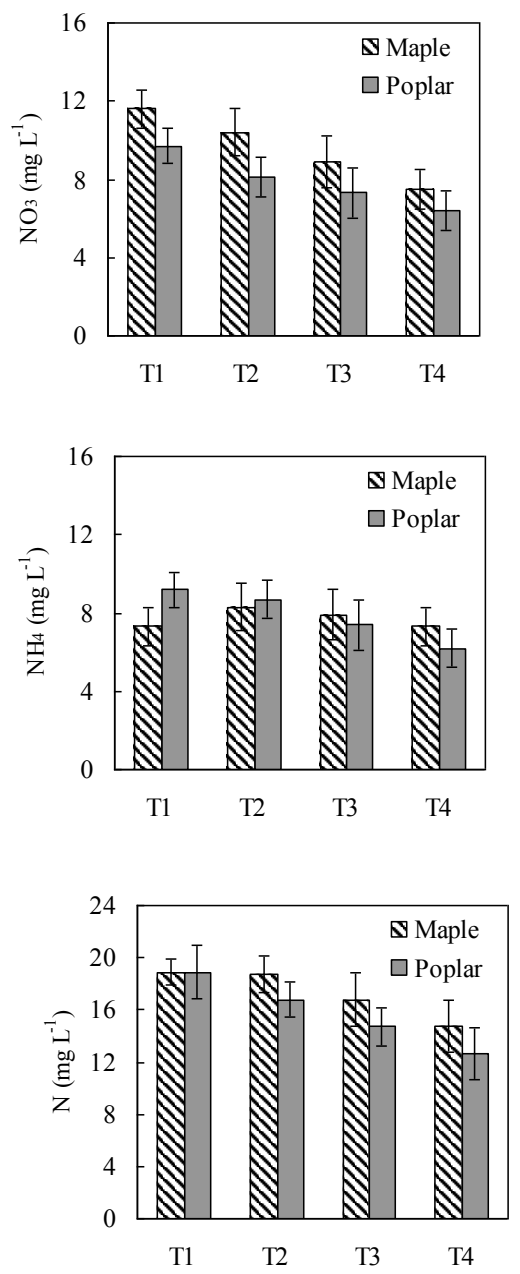

Manure-leaf litter treatments

Figure 2. $\mathrm{NO}_{3}, \mathrm{NH}_{4}$ and $\mathrm{N}$ in runoff water from soils treated with co-composted manure -leaf litter amendments at a rate of $20 \mathrm{tha}^{-1}$. 


\subsection{Phosphorus concentration}

The mean concentrations of $\mathrm{P}$ in runoff water following three consecutive natural rainfall events from co-composted manure amended soils are presented in Figure 3 and 4. Generally, the average concentrations of $\mathrm{P}$ in the runoff water decreased with increasing ratios of leaf litter in the co-composted manure treated soils. Phosphorus losses in the runoff water also increased with higher manure application rates. For example, for the sandy loam soil, amendment with the co-composted manure/maple residue resulted in $\mathrm{P}$ loss to runoff water which ranged from 5.6 to $2.7 \mathrm{mg} \mathrm{L}^{-1}$ at $10 \mathrm{tha}^{-1}$ and from 7 to $4.9 \mathrm{mg} \mathrm{L}^{-1}$ at $20 \mathrm{t} \mathrm{ha}^{-1}$, respectively. Compared to a control treatment (1:0) where leaf litter was not added, application of manure co-composted with leaf litter profoundly decreased $\mathrm{P}$ losses from soil to runoff with the silt loam soil releasing P more than the sandy loam soil. Irrespective of the soil type and application rate, co-composted manure with poplar leaf litter reduced $\mathrm{P}$ loss to

Sandy loam
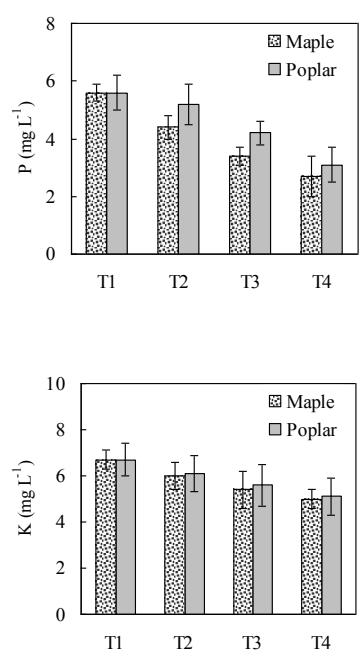

runoff in the order 1:0>1:1>1:2>1:3 (manure: poplar). Thus for the silt loam soil increasing amounts of poplar to the co-compost in the order 1:1, 1:2 and 1:3 (manure: poplar) decreased $\mathrm{P}$ content in the runoff in the order 6.2 $>5.6>5 \mathrm{mg} \mathrm{L}^{-1}$ and $4.9>3.6>3.1 \mathrm{mg} \mathrm{L}^{-1}$ at application rates of 20 and $10 \mathrm{tha}^{-1}$, respectively.

\subsection{Potassium concentration}

While the total $\mathrm{K}$ concentration in runoff water varied significantly amongst treatments (Figure 3-4). Relative to the control manure treatment (without tree litter additives), all co-composted manure treatments resulted in the substantial reductions in total $\mathrm{K}$ losses to runoff (Figure 3-4). For all treatments, a lower rate of co-composted manure amendment (i.e. $10 \mathrm{t} \mathrm{ha}^{-1}$ ) resulted in considerably reduced total $\mathrm{K}$ losses to runoff compared to the higher application rate of $20 \mathrm{t} \mathrm{ha}^{-1}$ for both sandy loam and silt loam soils. $\mathrm{K}$ losses from soils decreased with increasing amounts of leaf litter supplements in the composted manures.
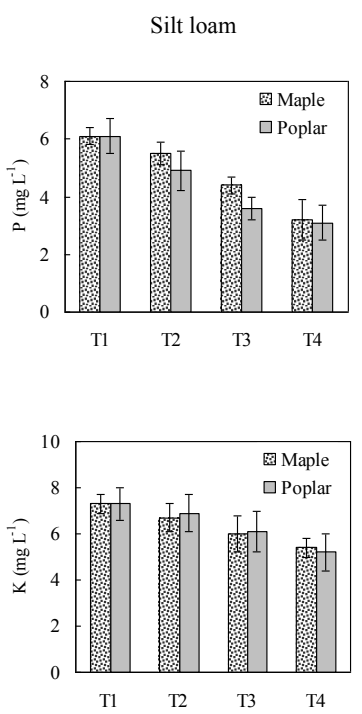

Manure-leaf litter treatments

Figure 3. $\mathrm{P}$ and $\mathrm{K}$ in runoff water from soils treated with co-composted manure -leaf litter amendments at a rate of $10 \mathrm{tha}^{-1}$. 
Sandy loam
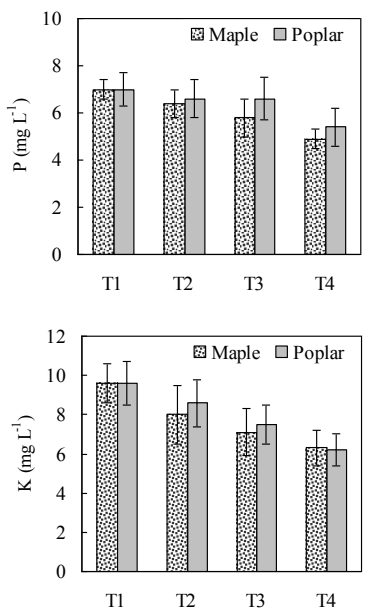

Silt loam
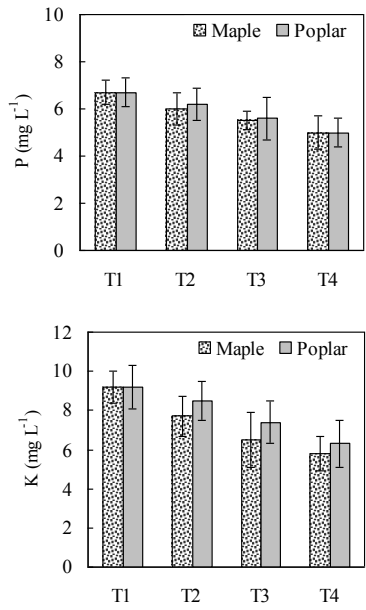

Manure-leaf litter treatments

Figure 4. $\mathrm{P}$ and $\mathrm{K}$ in runoff water from soils treated with co-composted manure -leaf litter amendments at a rate of $20 \mathrm{t} \mathrm{ha}^{-1}$.

\section{Discussion}

Application of co-composted manure in soils reduced the concentrations of inorganic $\mathrm{N}$ in runoff water irrespective of the ratio of leaf litter. Higher application of manure gave higher amount of $\mathrm{N}$ in the runoff water. The $\mathrm{N}$ concentration was negatively related to the amount of leaf additives in the manure applied. Maple leaf litter released more $\mathrm{N}$ than poplar leaf litter. Silt loam soil gave higher concentration of $\mathrm{N}$ as compared to sandy loam soil across all manure treatments. Nitrogen losses in the runoff were lowered with manure co-composted with leaf litter regardless of soil and application rates. These results are similar to those reported in previous studies. For example, a mixture of biosolid and yard waste delayed and reduced the volume of runoff under brief simulated rainfall events (Persyn et al., 2004). Similarly, lower N runoff was reported following a stimulated rainfall event when bare subsoil was top-dressed with bio-solids and yard waste (Glanville et al., 2004).

The concentrations of $\mathrm{NO}_{3}$ and $\mathrm{NH}_{4}$ in runoff decreased with the addition of co-composts to the soils. Nitrate and $\mathrm{NH}_{4}$ concentrations in the runoff water were inversely related with the ratios of co-composted leaf litter applied and the concentrations in the runoff from soils increased with the higher application of co-compost amendment. The concentration of $\mathrm{NH}_{4}$ in the runoff from both soils decreased with the increasing amount of leaf litter in the manure amendment. Increased leaching of $\mathrm{N}$ compounds from the sandy loam soil relative to the silt loam soil were attributed to soil properties i.e., increased water stable aggregates and increased water holding capacity by diminishing rainfall detachment (Wortmann and Walters, 2007; Rees et al., 2011). Co-composts of both 
maple and poplar leaf litter were effective in lowering $\mathrm{N}$ runoff losses. The slow mineralization of $\mathrm{N}$ compounds from co-composts ultimately minimized $\mathrm{NO}_{3}-$ $\mathrm{N}$ losses from the amended soils (Sims, 1990) and/ or the runoff volume decreased because of co-composted maple and poplar trees litter (Liu et al., 2012; Sadegi et al., 2015) and compost (Wortmann and Walters, 2007; Reddy et al., 2013). Glanville et al., (2004) had previously observed low $\mathrm{NO}_{3}$ losses $\left(0.2 \mathrm{mg} \mathrm{L}^{-1}\right)$ in runoff water from soils amendment with a mixture of biosolids yard waste on a roadside embankment. Phosphorus losses in the runoff waters also increased with higher application rate of composted manure. Mean concentrations of $\mathrm{P}$ in the runoff water decreased with increasing ratios of leaf litter in the manure treated soils. Poplar leaf litter gave higher magnitude of $\mathrm{P}$ in the sandy loam soil whereas maple leaf litter enhanced $\mathrm{P}$ in the silt loam soil. The duration between manure application and the rainfall event is an important factor in determining $\mathrm{P}$ release from agricultural lands (Ortega-Achury et al., 2007). Compared to a control manure treatment (1:0) where leaf litter was not added, application of manure co-composted with leaf litter profoundly decreased P losses from soil to runoff with the silt loam soil releasing $\mathrm{P}$ more than the sandy loam soil. Irrespective of the soil type and application rate, co-composted manure with poplar leaf litter reduced $\mathrm{P}$ loss to runoff in the order $1: 0>1: 1>1: 2>1: 3$ (manure: poplar). Thus for the silt loam soil increasing amounts of poplar to the cocompost in the order 1:1, 1:2 and 1:3 (manure: poplar) decreased $\mathrm{P}$ content in the runoff in the order $6.2>5.6$ $>5 \mathrm{mg} \mathrm{L}^{-1}$ and $4.9>3.6>3.1 \mathrm{mg} \mathrm{L}^{-1}$ at application rates of 20 and $10 \mathrm{t} \mathrm{ha}^{-1}$, respectively. Tarkalson and Mikkelsen (2007) had also supported an increased total P loss with increased application rates of broiler litter. Gilley et al. (2002) previously reported that while manure and compost application to soil did not increase dissolved and bioavailable fractions of $\mathrm{P}$ in the runoff volume, they did increase the total amount of $\mathrm{P}$ in runoff. In subsequent studies the same group found that tillage with cattle manure application significantly lowered dissolved $\mathrm{P}$, particulate $\mathrm{P}$, and total $P$ whilst disking with cattle manure amendment did not significantly reduce $\mathrm{P}$ constituents in the runoff volume (Gilley et al., 2007). The observed substantial reduction of nutrient losses from soil to runoff was attributed to an increase in water stable aggregates in soils after co-composts and compost application (McDowell and Sharpley, 2001). Tejada et al. (2009) also reported the importance of organic amendments in ameliorating soil composition by accommodating the stimulation and development of flocculation of clay minerals, which further promoted aggregation of soil particle. The concentrations of $P$ in runoff increased linearly with manure application rates.

Potassium concentration in runoff water was affected by the manure treatments in both soils. Composted manure decreased the amount of $\mathrm{K}$ losses in the runoff. The $\mathrm{K}$ contents in runoff generated from silt loam soil treated with 1:3, 1:2 and 1:1 manure: poplar amendments were 6.3, 7.4 and 8.5 $\mathrm{mg} \mathrm{L}^{-1}$, respectively. Lower runoff losses following compost manure amendments have been reported compared to no compost manure application (Wortmann and Walters 2006; Rees et al., 2011). These conflicts may be attributed to different timings between the compost (control) and co-composts additions and application of lower fractions of tree litter. Here different rainfall timings and other conditions which varied compared to the other cited studies. For instance, Wortmann and Walters (2006) had applied manure on the soil surface for three consecutive years prior to conducting their study, and under natural rainfall conditions runoff was calculated, whilst our study only examined the runoff losses of nutrients after three days of application in the experimental soils (sandy loam and silt loam) under natural rainfall events. Following manure application, these studies showed 
improved soil properties thereby, increasing infiltration rates, which is likely to be occurred over time as manure required time to interact with the soil to influence its properties. Hazbavi and Sadeghi (2016) stipulated that a single application of vinasse alone did not potentially impact/control runoff losses nor soil erosion. Sandy loam soil treated with $10 \mathrm{tha}^{-1}$ resulted in $\mathrm{K}$ concentration as $6.0,5.4$ and $5.0 \mathrm{mg} \mathrm{L}^{-1}$ in $1: 1,1: 2$ and 1:3, manure: maple treatments, respectively. Runoff losses following addition of either a 1:3 mixture of composted cow manure and maple tree residue or cocomposted cow manure: poplar tree litter amendment, in either sandy loam or silt loam soils, at application rates of 10 and $20 \mathrm{t} \mathrm{ha}^{-1}$, were lower than other ratios (1:2. 1:1 and 1:0). Birru et al. (2012) reported reduction in the runoff losses following the application of straw mulch in clayey soil under agro-climatic conditions. Similarly, the average sediment concentration and soil loss at stimulated rainfall intensities of 30 , 50,70 and $90 \mathrm{~mm} \mathrm{~h}^{-1}$ demonstrated the effectiveness of straw mulch, manure and TA-200 polyacrylamide in lowering the concentration and losses (Sadeghi et al., 2015). Asma et al. (2017) reported that the application of PL co-composted with sugarcane and cabbage wastes was found beneficial to maize growth and moderating soil $\mathrm{P}$ availability.

\section{Conclusions}

Soils amended with co-compost containing increasing amounts of either maple or poplar leaf litter relative to cow manure reduced apparent nutrient concentrations in runoff water. Higher manure applications enhanced nutrients losses in the runoff. Higher losses of plant nutrients were noticed in the early rainfall events. Manure amendments after compoting with plant litter was found a productive option in lowering nutrients losses from soils. Further studies are required to understand the implication to the soils hydrological properties following annual applications of such cocomposts to the soils.

\section{References}

Asma, S., Irshad, M., Hassan, A., Mahmood, Q. and Eneji, A. E. 2017. Bioavailability and extractability of phosphorus from soils amended with poultry manure after a co-composting. J. Soil Sci. Plant Nutr. 17: 609-623.

Birru, O., Quraishi, S. and Bedadi, B. 2012. Effect of straw mulch and farmyard manure, erosion, in-situ water conservation, yield and yield components of wheat at the highlands of Bale, South Eastern Ethiopia. Afr. J. Agric. Res. 7: 5879-5886.

Cerdà, A. and Doerr, S.H. 2008. The effect of ash and needle cover on surface runoff and erosion in the immediate post-fire period. Catena 74: 256-263.

Easton, Z.M., Petrovic, A.M. 2004.Fertilizer source effect on ground and surface water quality in drainage from turfgrass. J. Environ. Qual. 33: 645-655.

Gilley, J.E., Eghball, B., Marx, D.B. 2007. Nutrient concentrations of runoff during the year following manure application. Trans. ASABE 50: 1987-1999.

Gilley, J.E., Risse, L.M., Eghball, B. 2002. Managing runoff following manure application. J. Soil Water Conserv. 57: 530-533.

Glanville, T.D., Persyn, R.A., Richard, T.L., Laflen, J.M., Dixon, P.M. 2004. Environmental effects of applying composted organics to new highway embankments: part 2. water quality. Transactions of the American Society of Agricultural Engineers 47: 471-478.

Hazbavi, Z., Sadegi, S.H.R. 2016. Potential effects Vinasse as a soil amendment to control runoff and soil loss. Soil 2: 71-78. 
Hubbe, M.A., Nazhad, M., Sánchez, C. 2010. Composting as a way to convert cellulosic biomass and organic waste into high-value soil amendments: a review. Bioresour. 5: 2808-2854.

Irshad, M., Gul, S., Eneji, A.E., Anwar, Z., Ashraf, M. 2014. Extraction of heavy metals from manure and their bioavailability to spinach after composting. J. Plant Nutr. 37:1661-1675.

Laguë, C., Landry, H., Roberge, M. 2005. Engineering of land application systems for livestock manure: a review. Canad. Biosyst. Eng. 47: 617-628.

Liu, Y., Taoa, Y., Wana, K.Y., Zhanga, G. S., Liub, D.B., Xiongb, G.Y., Chena, F.2012. Runoff and nutrient losses in citrus orchards on sloping land subjected to different surface mulching practices in the danjiangkou reservoir area of China. Agric. Water Manage. 110: 34-40.

Mahmood, F., Khan, I., Ashraf, U., Shahzad, T., Hussain, S., Shahid, M., Abid, M., Sami Ullah 2017. Effects of organic and inorganic manures on maize and their residual impact on soil physicochemical properties. J. Soil Sci. Plant Nutr. 17: 22-32.

McDowell, R.W., Sharpley, A.N. 2001. Approximating phosphorus release from soils to surface runoff and subsurface drainage. J. Environ. Qual. 30: 508-520.

Neves, L., Ferreira, V. and Oliveira, R. 2009. Co-composting cow manure with food waste: The influence of lipid content. World Acad. Sci. Eng. Tech. 58: 986-991.

Ortega-Achury, S. L., Martinez- Rodriguez, G. A., Sotomayor- Ramirez, D. and Munoz- Munoz, M.A. 2007. Nutrient concentration in runoff from different manure amended fields of the tropics under natural rainfall conditions. J. Agric. Univ. P. R. 91: 101-115.
Persyn, R.A., Glanville, T.D., Richard, T.L., Laflen, J.M., Dixon, P.M. 2004. Environmental effects of applying composted organics to new highway embankments: part 1. Interrill runoff and erosion. Transactions of the American Society of Agricultural Engineers 47: 463-469.

Reddy, N., Crohn, D.M., Ernst, F.F., Chaganti, V.N. 2013. Characterizing water holding capacity and runoff during composing of green waste and biosolids. Compost Sci. Util. 21: 164-176.

Rees, H.W., Chow, T.L., Zebarth, B.J., Xing, Z., Toner, P., Lavoie, J., Daigle, J.L. 2011. Effects of supplemental poultry manure applications on soil erosion and runoff water quality from a loam soil under potato production in north-western New Brunswick. J. Soil Sci. 91: 595-613.

Reynolds, M.A. 2006. Managing livestock manure to protect environmental quality. University of $\mathrm{Ne}-$ braska Cooperative Extension, EC 02-179. Lincoln, Neb.: University of Nebraska Cooperative Extension.

Rodriguez, E.G., Alonso, J., Melgar, M.J., Vázquez, M. 2006. Evaluation of heavy metal contents in co-composts of poultry manure with barley wastes or chestnut burr/leaf litter. Chemosphere 65: 1801-1805.

Sadegi, S.H.R., Gholami, L., Homaee, M., Darvishan, A.K. 2015. Reducing sediment concentration and soil loss using organic and inorganic amendments at plot scale. Solid Earth 6: 445-455.

Shah, G.M., Shah, G.A., Groot, J.C.J., Raza, M.A.S., Shahid, N. Lantinga, E.A. 2016. Maize nitrogen recovery and dry matter production as affected by application of solid cattle manure subjected to various storage conditions. J. Soil Sci. Plant Nutr. 16: 591-603. 
Sims, J.T. 1990. Nitrogen mineralization and elemental availability in soils amended with cocomposted sewage sludge. J. Environ. Qual. 19: 669-675.

Subair, S., Fyles, J.W., O'Halloran, I.P.1999. Ammonia volatilization from liquid hog manure amended with paper products in the laboratory. J. Environ. Qual. 28: 202 - 207.

Tarkalson, D.D., Mikkelsen, R.L. 2007. P losses in runoff after application of litter from Broiler fed High Available P Corn feed. Commun. Soil Sci. Plant Anal. 38: 1805-1814.

Tejada, M., Gonzalez, J.L. 2008. Influence of two organic amendments on the soil physical properties, soil losses, sediments and runoff water quality. Geoderma 145: 325-334.

Tejada, M. and Gonzalez, J.L. 2006. The relationships between erodibility and erosion in a soil treated with two organic amendments. Soil Till. Res. 91: 186-198.

Tejada, M., Garcia-Martinez, A.M., Parrado, J. 2009. Effects of a vermicompost composted with beet vinasse on soil properties, soil losses and soil restoration. Catena. 77: 238-247.
Turner, R.E., Rabalais, N.N., Dortch, Q., Justic, D., Gupta, B.K.1997. Evidence for nutrient limitation on sources causing hypoxia on the Louisiana shelf. In: Proc. 1st Gulf of Mexico Hypoxia Management Conference, 112-119. Cincinnati, Ohio: Labat-Anderson, Inc.

Wortmann, C.S., Walters, D.T. 2007. Residual effects of compost and plowing on phosphorus and sediment in runoff. J. Environ. Qual. 36: 1521-1527.

Wortmann, C.S., Walters, D.T. 2006. Phosphorus runoff during four years following composted manure application. J. Environ. Qual. 35: 651-657.

Wright, A.L., Provin, T.L., Hons, F.M., Zuberer, D.A., White, R.H. 2007. Nutrient accumulation and availability in compost amended turfgrass soil. Hort. Sci. 42: 1473-1477.

Zhang, Y., He, Y. 2006. Co-composting solid swine manure with pine sawdust as organic substrate. Bioresour. Technol. 97: 2024-2031. 